p 61-65. In: Hare, M.D.; Brock, J.L., editors. Producing Herbage Seeds.

Grassland Research and Practice Series No. 2,

New Zealand Grassland Association, Palmerston North.

\title{
CONTAMINATION OF WHITE CLOVER SEED CROPS BY BURIED SEEDS
}

\section{J A. Lancashire'}

\section{M.P. Rolston'}

D.J. Scott*

${ }^{1}$ Grasslands Division, DSIR, Palmerston North and *Seed Testing Station, MAF, Palmerston North

\begin{abstract}
Thirty five certified seed lines of 'Grasslands Pitau' white clover produced under OECD rules showed marked variations in growth and morphological characteristics according to their region of origin. Of lines grown in Oamaru district, South Canterbury, $90 \%$ were significantly different from a Pitau breeders (pre-basic) line in winter growth scores, leaf size and picric acid scores. $90 \%$ of lines grown in Marlborough were similar to a Pitau breeders line.

Buried white clover seed counts were $260 / \mathrm{m}^{2}(2 \mathrm{~kg} / \mathrm{ha})$ in Marlborough and $1060 / \mathrm{m}^{2}(7.5 \mathrm{~kg} / \mathrm{ha})$ in Oamaru. Plants grown from buried seed collected in Canterbury generally had smaller leaves, less winter growth and lower picric acid scores than Pitau. The additional possibility that natural selection of genotypes occurred because some crops of Pitau have been grown under climates and/or managements to which it is not adapted, is also discussed.

Preliminary studies of 43 commercial lines of 15 cultivars from 4 countries grown outside New Zealand indicated that $3540 \%$ showed significant differences in winter growth and leaf size between lines of the same cultivar. New Zealand grown commercial lines of Huia obtained overseas showed good uniformity.

It appears that there is a world-wide problem of genetic contamination in white clover cultivars. High buried seed loads are a potential long term source of contamination which is being exaggerated by the increasing numbers of cultivars. New Zealand has already moved to implement tighter certification standards than those recommended by OECD.

Keywords: Trifolium repens, 'Grasslands Pitau', buried seed, seed certification, OECD, genetic contamination.
\end{abstract}

\section{INTRODUCTION}

The successful use of white clover (Trifolium repens L.) in New Zealand pastures has been largely based on one cultivar 'Grasslands Huia' (first released in 1936), which has proved well adapted to a wide range of environments and farming systems (Corkill et al., 1981). The species is present in virtually all pasture seeds mixtures and, as a result of this widespread use and its ability to set seed, many grassland soils contain high buried seed loads of white clover, particularly in seed production areas. In addition, 90\% of this seed is usually dormant or hard. This poses potentially severe contamination problems for a seed grower who wishes to grow cultivars other than Huia (Lancashire et al., 1980).

The recent release of a new cultivar of white clover, 'Grasslands Pitau', for widespread commercial multiplication in New Zealand, provided the opportunity of studying the problem in detail. This cultivar shows greater cool-season activity and is more erect and has larger leaves than Huia (Williams, 1980). It is also slightly earlier flowering (P.T.P. Clifford, pers. comm.).

\section{EXPERIMENTAL}

Thirty five samples of certified Pitau lines from the 1981/82 harvest (all first harvests), grown largely in 3 regions and representing different grades of certification, were grown out as spaced plants at the Grasslands Division Aorangi research farm, Manawatu (Table 1).

TABLE 1 Origin of 35 certified Pitau seed lines from the 1981-82 harvest.

\begin{tabular}{lclr}
\hline District & \multicolumn{3}{l}{ Generation } \\
\hline Ashburton & 16 & Basic & 17 \\
Oamaru & 9 & 1st Generation & 16 \\
Marlborough & $\mathbf{8}$ & 2nd Generation & 2 \\
Invercargill & 1 & & \\
Timaru & 1 & & \\
\hline
\end{tabular}

Plants were raised in the glasshouse and planted out in a randomised block design with 2 replications, each containing 49 plants (7 rows of 7 plants) in December 1982. Pitau nucleus and Pitau breeders (pre-basic) lines were used as controls and samples of Huia and 'Grasslands Tahora' (a recently released small leaved hill country type) were also included for comparative purposes. The Pitau nucleus seed was grown at DSIR, Lincoln in 1973/74 and the breeders line at Maryburn Station, Fairlie in $1974 / 75$. All the other seed lines grown in the 
TABLE 2 Winter growth scores (1983) of certified Pitau lines from different regions compared with Pitau breeders set at 100. Means for 1984 in parentheses.

\begin{tabular}{|c|c|c|c|c|c|c|c|c|c|c|c|}
\hline \multirow{2}{*}{$\begin{array}{l}\text { Origin of seed line } \\
\text { Ashburton }\end{array}$} & \multicolumn{8}{|c|}{ Growth scores } & \multicolumn{3}{|c|}{ Means } \\
\hline & $\begin{array}{l}57 \\
85\end{array}$ & $\begin{array}{l}70^{*} \\
74^{*}\end{array}$ & $\begin{array}{l}69^{*} \\
75^{*}\end{array}$ & $\begin{array}{l}83 \\
88\end{array}$ & $\begin{array}{l}82 \\
88\end{array}$ & $\begin{array}{l}83 \\
76^{*}\end{array}$ & $\begin{array}{l}71^{*} \\
79^{*}\end{array}$ & $\begin{array}{l}85 \\
96\end{array}$ & & $79^{*}$ & $\left(78^{\prime}\right)$ \\
\hline Oamaru & $62^{*}$ & $66^{*}$ & $69^{*}$ & $70 ”$ & $74^{*}$ & $76^{*}$ & $77^{*}$ & $77^{*}$ & 87 & $73^{*}$ & $\left(74^{*}\right)$ \\
\hline Marlborough & $79^{*}$ & 85 & 88 & 90 & 91 & 95 & 96 & 101 & & 91 & $(88)$ \\
\hline Invercargill & 101 & & & & & & & & & & \\
\hline Timaru & 78 & & & & & & & & & & \\
\hline Huia breeders & $64^{*}$ & & & & & & & & & & \\
\hline Tahora nucleus & $52 *$ & & & & & & & & & & \\
\hline
\end{tabular}

* Lines significantly different from Pitau breeders (100). LSD 5\% 19.

trial originated from the breeders seed grown at Fairlie or one grown at Te Anau on new land development areas which were completely free of buried white clover seed.

Following satisfactory establishment, plants were periodically mob-grazed by sheep (for a maximum of 2 days) and visually scored on a O-S scale for growth before each grazing, over the next 2 years. Particular care was taken to avoid contamination of the area by other white clover plants or seeds, by regular interrow cultivation and by reducing the amount of flowering and seed set as far as possible. Flowering dates, leaf size measurements (Williams et al., 1964) and picric acid tests for cyanogenesis (Corkill, 1942) (only on a representative selection of lines) were also made at intervals. Preliminary results are presented below; full data are available from the senior author.

\section{RESULTS}

Comparative growth scores for winter 1983 (Table 2) showed that all the lines from Oamaru except one and $50 \%$ of the lines from Ashburton had significantly less winter growth than the Pitau breeders line. In contrast, only one line from Marlborough was significantly different.

The broadly similar results obtained in winter 1984 (Table 2) confirmed these results and also suggest that attempts to control contamination of the experimental area were successful, at least in the short term. There were no differences between the relative growth scores of basic (79) and first generation lines (81).

As with the winter growth data, measurements of other characteristics (Table 3), confirmed that lines from Marlborough were generally fairly similar to the Pitau breeders line but that Ashburton and, in particular, Oamaru lines showed marked differences.

TABLE 3 Characteristics of certified Pitau lines from different regions.

\begin{tabular}{lccc}
\hline & $\begin{array}{c}\text { Leaf Size } \\
\left(\mathbf{c m}^{\mathbf{2}}\right)\end{array}$ & $\begin{array}{c}\text { Picric Acid } \\
\text { Scores } \\
\mathbf{( 0 - 5 ) ^ { 1 }}\end{array}$ & \multicolumn{2}{c}{$\begin{array}{c}\text { \% Plants } \\
\text { Flowering In } \\
\text { October 1983 }\end{array}$} \\
\hline Pitau Breeders & 11.9 & 4.2 & 12.2 \\
Marlborough & 11.0 & 3.5 & 8.2 \\
Ashburton & 9.1 & 3.3 & 4.7 \\
Oamaru & 8.2 & 2.8 & 2.3 \\
Huia Breeders & 4.7 & 2.6 & 0 \\
Tahora Nucleus & 2.3 & 1.9 & 0 \\
\hline
\end{tabular}

1 Highest value indicates most intense reaction.

\section{DISCUSSION}

Although all the information on factors which may have produced these results (e.g. cultural practices (Clifford et al., 1985)) has not been fully analysed, it appears that there was no relationship between certification grade of the harvested crop, season and year of sowing, and grade of seed sown, which would have confounded the overall regional effect (Table 4). In addition, although 22 of the paddocks were known to have grown Huia for seed in the past 15 years (no information was available on 13 paddocks), there was no apparent relationship between the time of occurrence of

TABLE 4 Details of Pitau seed crops harvested in 1981-82 (all first harvests).

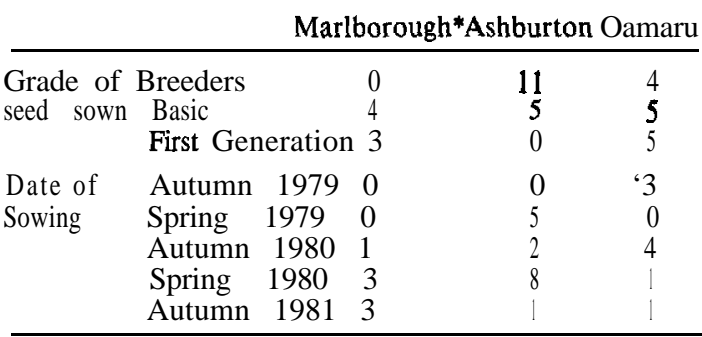

* Some information for 1 area not available. 
these crops and the performance of the spaced plants.

As the number of legume cultivars has increased in New Zealand in recent years (Lancashire, 1978), it has been 'the policy of Grasslands Division (in conjunction with Ministry of Agriculture and Fisheries specialist advisory officers) to sample all areas submitted for breeders seed production for buried seed content. The counts shown in Table $\mathbf{S}$ suggest that buried seed loads are considerably lower in the Marlborough district than in midCanterbury or North Otago, and therefore the potential for contamination from this source, particularly of seed crops of new cultivars, would be expected to be less.

TABLE 5 White clover buried seed counts as no/m' during 1979-83. ( $\mathrm{kg} / \mathrm{ha}$ in parenthesis).

\begin{tabular}{lccc}
\hline District & $\begin{array}{r}\text { Number } \\
\text { samples }\end{array}$ & Mean & \multicolumn{2}{c}{$\begin{array}{c}\text { White } \\
\text { Range }\end{array}$} \\
\hline $\begin{array}{l}\text { Marlborough } \\
\text { Mid-Canterbury } \\
\text { (includes Ashburton) }\end{array}$ & 160 & $1390(10.0)$ & $0-17,920(0-128)$ \\
$\begin{array}{l}\text { North Otago } \\
\text { (includes Oamaru) }\end{array}$ & 57 & $1060(7.5)$ & $\mathbf{4 0 - 3 , 0 0 0 ( 0 . 3 - 2 1 )}$ \\
\hline
\end{tabular}

However, this potential will depend on the genetic characteristics of the plants which develop from the buried seed. As part of a general project on this problem, plants grown from buried seed obtained from areas entered for Huia breeders seed productrion in 1979, largely in the Ashburton area, were grown as spaced plants (6 replications of 10 plants) at Palmerston North in $1980 / 8$. The summary of these results (Table 6) indicates that many of the areas contained plants which were significantly different from Huia and, in the characteristics measured, would have shown even greater divergence from Pitau.

TABLE 6 Some characteristics of white clover plants grown from buried seed obtained from 20 areas (15 Ashburton, 3 Timaru, 2 Rangiora) entered for Huia breeders seed production in 1979. Control. Huia nucleus.

Character Results

Growth score in

Autumn/Winter $\quad \mathbf{3 5 - 4 0 \%}$ had significantly less growth

Growth score in

Spring/Summer $\quad \mathbf{1 0 - 2 0 \%}$ had significantly less growth

Leaf size $\quad \mathbf{7 5 - 8 5 \%}$ had significantly smaller leaves

Cyanogenesis level $85 \%$ had a significantly lower score

A further indication of the potential longterm nature of the contamination problem was illustrated by a recent examination of buried seeds obtained from 2 areas which had grown S100 Nomark white clover for seed production in 1968/69 and 1970/71 (E.R. Kevern, pers. comm.). $22-25 \%$ of the plants grown from scarified samples of the buried seed had no leaf marks, the characteristic of $\mathrm{S} 100$ Nomark. This was despite the fact that both areas had been through several crop rotations including, in one case, 3 Huia seed crops.

Another factor that must be considered in explaining these regional differences is the possibility that natural selection of genotypes may occur if the cultivar is grown in areas and/or under managements to which it is not adapted. Pitau white clover has generally shown greater yield advantage over Huia in the cool season, in warmer latitudes (Hoglund and Brock, 1974) and under rotational grazing (Brock, 1974). Thus, the potential seed yield of Pitau is likely to be higher in the warmer climate of the Marlborough region than Ashburton or Oamaru (P.T.P. Clifford, pers. comm.). However, to date, greater yields of commercial crops have been obtained in the traditional clover seed growing areas of Canterbury. In addition, the original breeders seed crops, which have proved true to type, were grown at Fairlie and Te Anau in areas free of buried seed but considerably cooler than Marlborough. Further work is required to clarify the possibility of genetic shift occurring, particularly in cases where successive crops are taken in cooler areas where hard grazing is practised.

\section{OVERSEAS CULTIVARS OF WHITE CLOVER}

As the variation in the Pitau seed lines had occurred in New Zealand despite all crops being grown under OECD seed certification regulations, it was important to assess whether similar problems were evident in other countries. During 1983 samples of 43 overseas lines of 15 cultivars from 4 countries and 10 Huia lines were purchased through normal commercial outlets in the United Kingdom. Most of the lines were first generation with the remainder being basic or pre-basic. Plants were raised in the glasshouse and, along with control lines obtained from the breeders of each cultivar, planted out in randomised blocks of spaced plants (6 replications of 20 plants) in autumn 1984. Similar measurements were made as in the Pitau trial and preliminary results are presented in Tables 7 and 8 . 
TABLE 7 Range of growth scores for some overseas white clover cultivars at the end of the first winter, September 1984 (mean of 20 plants).

\begin{tabular}{ll}
\hline Cultivar & Range \\
\hline Aran & $50.6 \cdot \mathbf{6 7 . 8 *}$ \\
Blanca & $38.6 \cdot \mathbf{5 3 . 8 ^ { * }}$ \\
Milkanova & $36.0 \cdot \mathbf{5 2 . 0 ^ { * }}$ \\
Sabeda & $27.4 \cdot \mathbf{4 1 . 8 ^ { * }}$ \\
S184 & $23.6 \cdot \mathbf{4 1 . 0 ^ { * }}$ \\
Huia & $42.9 \cdot 52.8 \mathrm{~ns}$ \\
& *L.S.D. 5\% $=14.3$ \\
\hline
\end{tabular}

TABLE 8 Range of leaf sizes for some overseas white clover cultivars, December 1984. Mean of 20 plants $(10 \mathrm{x} \log$ of 10 $x$ Area).

\begin{tabular}{lc}
\hline Cultivar & Range \\
\hline Aran & $20.0 \cdot 21.8^{*}$ \\
Blanca & $17.8 \cdot 19.4^{*}$ \\
Menna & $16.9 \cdot 18.5^{*}$ \\
Milkanova & $17.5 \cdot 19.6^{*}$ \\
Sabeda & $17.3 \cdot 19.2^{*}$ \\
S184 & $14.3 \cdot 16.6^{*}$ \\
Huia & $17.7 \cdot 18.8 \mathrm{~ns}$ \\
& "L.S.D. 5\% $=1.46$ \\
\hline
\end{tabular}

Of the cultivars produced overseas $35-40 \%$ showed significant differences in growth and leaf size between lines of the same cultivar. Further data need to be collected before these lines can be fully assessed, but the results indicate that the problem of variation in certified white clover lines is world-wide. Interestingly, the 10 Huia lines have proved fairly uniform so far, and this may reflect the fact that until recently it was the only cultivar produced in New Zealand.

\section{CONCLUSIONS}

As New Zealand is the major supplier of white clover seed to the world market these results are of particular significance. However, as the number of white clover cultivars increases throughout the world, plant breeders and agronomists in all countries must develop techniques which ensure the genetic integrity of their products. It appears that the current OECD seed certification regulations may not be adequate, and New Zealand has already moved to implement tighter standards (Clifford $\boldsymbol{e}$ t al., 1985). It is essential that these strategies are adopted by the seeds industry, so that New Zealand can maintain and enhance its reputation as a supplier of high quality, genetically true-to-type white clover seed to the world market.

\section{ACKNOWLEDGEMENTS}

Tom Lyons, Grasslands Division, for data collection and trial control; Peter McLaren, Grasslands Division, for assistance and James Milner, MAF, Palmerston North for setting up the trial.

\section{REFERENCES}

Brock, J.L., 1974. New Zealand Journal of Experimental Agriculture, 2: 365-9.

Clifford, P.T.P.; Rolston, M.P.; Williams, W.M., 1985. p 67-73. In: Hare, M.D.; Brock, J.L., editors. Producing Herbage Seeds. Grassland Research and Practice Series No. 2, New Zealand Grassland Association, Palmerston North

Corkill, L., 1942. New Zealand Journal of Science and Technology, 23(B): 178-193.

Corkill, L.; Williams, W.M.; Lancashire, J.A., 1981. Proceedings of the $\mathbf{N e w}$ Zealand Grassland Association, 42: 100-122.

Hoglund, J.H.; Brock, J.L., 1974. New Zealand Journal of Agricultural Research, 17; $41-45$

Lancashire, J.A., 1978. Proceedings of the Agronomy Society of New Zealand, 8: 123-127.

Lancashire, J.A.; Gomez, J.S.; McKellar, A.D., 1980. p 80-86. In: Lancashire, J.A., editor. Herbage Seed Production. Grassland Research and Practice Series No. 1, New Zealand Grassland Association, Palmerston North.

Williams, R.F.; Evans, L.T.; Ludwig, L. J., 1964. Australian Journal of Agricultural Research, 15: 231-233.

Williams, W.M., 1980. AgLink FPP 347. MAF Information Services, Wellington.

\section{DISCUSSION}

Q. Couldsome of the variation you recorded in the clover seedlines be caused by genetic factors?

A. Probably not. There could, however, be regional effects in that Pitau will always grow better than volunteer white clover in the Marlborough region but probably not in South Canterbury, because of its Spanish parentage.

Q. Does the greater purity level of Pitau clover seedlots harvested in Marlborough indicate any solutions to the contamination problem?

A. Not really. Marlborough has not been producing white clover seed for long so has much lower levels of buried clover seeds, In addition, Pitau seems far better adapted to Marlborough's conditions so is more dominant over volunteer material.

Q. Are the certification authorities aware of this contamination work?

A. Yes. The results have been before the inter-industry committee for two years.

Q. To what degree is the $\mathrm{New} Z \mathrm{Z}$ ealand agriculturalsystem actually compromised by adhering to OECD rules? What is wrong with supplying seed lines contaminated 
with the same species to the New Zealand farmer?

A. Plant breeders try to produce better cultivars for our farmers. Contamination with poorer genotypes undoes plant breeding objectives. Multiplication of regional cultivars in the region where they will be used, might help solve this problem. However, more flexibility, in terms of genetic purity, is probably needed for the farmer.

Comment. Perhaps it is not economically worthwhile to remove all contamination from our clover seedlines, but more practical to accept a tolerable level.

Q. Would overseas countries be more convinced of the contamination problem if it was demonstrated to them in their own countries?

A. It is probably more important to test overseas lines of clovers, currently being multiplied here, to show that these were contaminated on arrival.

Q. Will the New Zealand climate produce some genetic shift in overseas clovers being multiplied here?

A. Current legislation does not cover that situation. The procedure should be that the breeder's agent submits samples of these lines to the Ministry of Agriculture and Fisheries for testing to ensure trueness to type and ability to produce adequate seed yields here.

Q. What arrangements are being made for marketing of Tahora hill country white clover?

A. Interim agents have been appointed for Tahora under the agenting agreement now drawn up between DSIR, the Agicultural Merchant's Federation and Federated Farmers. 